\title{
MAINTENANCE OF POTASSIUM EXCRETION DESPITE REDUCTION OF GLOMERULAR FILTRATION DURING SODIUM DIURESIS
}

\author{
By DOUGLAS G. DAVIDSON, NORMAN G. LEVINSKY, AND ROBERT W. BERLINER \\ WITH THE TECHNICAL ASSISTANCE OF AGNES SCOTT PRESTON
}

(From the Laboratory of Kidney and Electrolyte Metabolism, National Heart Institute, Bethesda, Md.)

(Submitted for publication September 9, 1957 ; accepted December 12, 1957)

It has been clearly established that mammalian renal tubules can secrete potassium. However, it has not been shown in mammals under physiologic conditions what proportion of the urinary potassium is derived from the filtered potassium and what proportion from secreted potassium. In experiments designed to study the various factors which influence potassium excretion it has sometimes been assumed that the reabsorption of the filtered potassium is essentially complete, and that these factors exert their effects on the secretory mechanism. However, evidence for the completeness of reabsorption of filtered potassium is limited and not conclusive.

The proposed tubular mechanism for the secretion of potassium is an ion exchange process in the distal tubule (1), where cellular potassium ions are exchanged for sodium ions derived from the glomerular filtrate. It is implicit in this mechanism that potassium secretion will depend in part on the availability of sodium ions for exchange. If the proximal reabsorption of filtered potassium is complete, the rate of excretion of potassium will be independent of the filtered load of potassium, providing an adequate distal load of sodium is maintained. To test this hypothesis, the glomerular filtration rate was reduced in one kidney and the rate of excretion of potassium from this kidney was compared to that of the control kidney, during both high and low rates of sodium excretion.

\section{METHODS}

Experiments were performed using trained unanesthetized female dogs weighing 18 to $22 \mathrm{Kg}$. During the experiments the dogs were standing, with light support from a sling. Multiple experiments have been done on eight dogs. In order to lower the glomerular filtration rate in one kidney, a small inflatable cufflike clamp was placed around the renal artery. In these experiments, the renal artery clamp was always placed around the right renal artery, because of the late branching of this artery as compared to the left renal artery. The clamp was seated around the unbranched renal artery as near as possible to its origin from the aorta. Separate urine collections from each kidney were made possible by a bladder splitting operation. The renal artery clamp and the method of separate urine collections from each kidney are described in detail in a previous communication from this laboratory ${ }^{1}$ (2).

Inulin was used to measure the glomerular filtration rate, and was determined by the method of Walser, Davidson, and Orloff (3). The clearance of para-aminohippurate $(\mathrm{PAH})$ was used as a measure of the effective renal plasma flow, and was determined by the method of Bratton and Marshall (4). Sodium and potassium in diluted plasma and urine were determined by flame photometry using lithium as an internal standard. Urine chloride was determined by potentiometric titration (5).

Constant rates of intravenous infusions were maintained by means of a Bowman infusion pump. In some of the experiments, mercurial diuretics, acetazolamide (Diamox (®) or $\mathrm{Na}_{2} \mathrm{SO}_{4}$ were given, often along with infusions of sodium chloride or bicarbonate, to assure a high rate of sodium excretion when the glomerular filtration rate was reduced.

\section{RESULTS}

\section{Reduction of the glomerular filtration rate during low rates of sodium excretion}

In contrast to the rest of the experiments to be presented, Tables I and II and Figure 1 present the data from seven experiments in four different dogs in which no attempt was made to maintain a high rate of sodium excretion when the glomerular filtration rate was reduced. These were selected as representative of about 100 such experiments done for various purposes other than the study of potassium excretion. In some of these experiments, mannitol was added to the infusions to maintain urine flows adequate for clearance measurements when the glomerular filtration rate was reduced. The first two to four periods in each

$1 \mathrm{We}$ are indebted to Dr. Edward Sharpe for the surgical preparations. 
TABLE I

Effect of lowering the glomerular filtration rate without $\mathrm{NaCl}$ diuresis

\begin{tabular}{|c|c|c|c|c|c|c|c|c|c|c|c|}
\hline \multirow{2}{*}{$\begin{array}{l}\text { Time } \\
(\min .)\end{array}$} & \multicolumn{2}{|c|}{$\begin{array}{c}\begin{array}{c}\text { Urine } \\
\text { flow } \\
\text { (ml./min.) }\end{array} \\
\end{array}$} & \multicolumn{2}{|c|}{$\begin{array}{c}\text { Inulin } \\
\text { clearance } \\
(m l . / m i n .)\end{array}$} & \multicolumn{2}{|c|}{$\begin{array}{c}\text { Excreted } \\
\mathrm{K} \\
(\mu E q . / \min .)\end{array}$} & \multicolumn{2}{|c|}{$\begin{array}{c}\text { Excreted } \\
\mathrm{Na} \\
(\mu \text { E. } / \text { min. })\end{array}$} & \multirow{2}{*}{$\begin{array}{l}\text { Glomerular } \\
\text { filtration } \\
\text { rate } \\
\text { R/L }\end{array}$} & \multirow{2}{*}{$\begin{array}{c}\text { Excreted } \\
\mathbf{K} \\
\mathbf{R} / \mathbf{L}\end{array}$} & \multirow{2}{*}{$\begin{array}{c}\text { Excreted } \\
\text { Na } \\
\mathbf{R} / \mathbf{L}\end{array}$} \\
\hline & $\mathbf{R}$ & $\mathbf{L}$ & $\mathbf{R}$ & L & $\mathbf{R}$ & $\mathbf{L}$ & $\mathbf{R}$ & $\mathbf{L}$ & & & \\
\hline $\mathbf{0}$ & \multicolumn{11}{|c|}{ Infusion: Inulin, $10 \mathrm{mg} . / \mathrm{min} . ;$ Pitressin $(100 \mathrm{mU} / \mathrm{Kg} . / \mathrm{hr}$. in $2.5 \% \mathrm{NaCl}$ solution at $0.5 \mathrm{ml} . / \mathrm{min}$. } \\
\hline $\begin{array}{l}30-60 \\
62-93 \\
96-123\end{array}$ & $\begin{array}{l}0.10 \\
0.10 \\
0.12\end{array}$ & $\begin{array}{l}0.12 \\
0.10 \\
0.13\end{array}$ & $\begin{array}{l}41.5 \\
44.4 \\
46.3\end{array}$ & $\begin{array}{l}48.0 \\
44.0 \\
46.5\end{array}$ & $\begin{array}{l}38.1 \\
34.3 \\
42.6\end{array}$ & $\begin{array}{l}44.0 \\
36.0 \\
44.1\end{array}$ & $\begin{array}{l}7.1 \\
3.7 \\
4.2\end{array}$ & $\begin{array}{r}10.8 \\
5.1 \\
5.7\end{array}$ & $\begin{array}{l}0.87 \\
1.01 \\
1.00\end{array}$ & $\begin{array}{l}0.87 \\
0.95 \\
0.97\end{array}$ & $\begin{array}{l}0.66 \\
0.73 \\
0.74\end{array}$ \\
\hline 125 & \multicolumn{11}{|c|}{ Clamp inflated right renal artery } \\
\hline $\begin{array}{l}187-208 \\
210-234 \\
235-257 \\
260-290\end{array}$ & $\begin{array}{l}0.10 \\
0.10 \\
0.12 \\
0.08\end{array}$ & $\begin{array}{l}0.23 \\
0.24 \\
0.28 \\
0.25\end{array}$ & $\begin{array}{l}40.4 \\
42.4 \\
44.7 \\
36.2\end{array}$ & $\begin{array}{l}54.2 \\
55.9 \\
60.3 \\
56.3\end{array}$ & $\begin{array}{l}37.1 \\
36.7 \\
43.6 \\
26.8\end{array}$ & $\begin{array}{l}64.4 \\
73.0 \\
89.0 \\
76.0\end{array}$ & $\begin{array}{l}2.6 \\
1.9 \\
2.7 \\
1.8\end{array}$ & $\begin{array}{l}33.0 \\
24.6 \\
37.0 \\
39.2\end{array}$ & $\begin{array}{l}0.75 \\
0.76 \\
0.74 \\
0.64\end{array}$ & $\begin{array}{l}0.58 \\
0.50 \\
0.49 \\
0.35\end{array}$ & $\begin{array}{l}0.08 \\
0.08 \\
0.07 \\
0.05\end{array}$ \\
\hline 292 & \multicolumn{11}{|c|}{ Clamp partially deflated } \\
\hline $\begin{array}{r}308-328 \\
329-349 \\
360-379 \\
381-396\end{array}$ & $\begin{array}{l}0.14 \\
0.19 \\
0.18 \\
0.17\end{array}$ & $\begin{array}{l}0.29 \\
0.31 \\
0.28 \\
0.27\end{array}$ & $\begin{array}{l}54.2 \\
61.0 \\
54.6 \\
49.0\end{array}$ & $\begin{array}{l}65.7 \\
63.4 \\
58.9 \\
54.3\end{array}$ & $\begin{array}{l}51.2 \\
61.1 \\
57.0 \\
47.6\end{array}$ & $\begin{array}{l}70.3 \\
72.5 \\
70.2 \\
75.6\end{array}$ & $\begin{array}{l}16.3 \\
27.6 \\
36.0 \\
38.5\end{array}$ & $\begin{array}{l}64.2 \\
69.6 \\
67.1 \\
64.6\end{array}$ & $\begin{array}{l}0.82 \\
0.96 \\
0.93 \\
0.90\end{array}$ & $\begin{array}{l}0.73 \\
0.84 \\
0.81 \\
0.63\end{array}$ & $\begin{array}{l}0.25 \\
0.40 \\
0.54 \\
0.60\end{array}$ \\
\hline
\end{tabular}

experiment were control periods, secured to compare the function of the two kidneys and especially to determine the ratio of the rates of excretion of potassium by the two kidneys. The absolute rate of potassium excretion from each kidney varies from period to period during the course of an experiment. No attempt has been made to define the many factors which affect this variation in potassium excretion. However, the assumption is made that these factors exert identical effects in both kidneys. Therefore, the effects of clamping the renal artery are interpreted in terms of changes in the ratio of the rates of excretion of potassium by the two kidneys, rather than in terms of changes in the absolute rate of potassium excretion by the "clamped" kidney.

Following the control periods, the glomerular filtration rate was reduced in the right kidney by inflating the clamp. Various levels of reduction of the glomerular filtration rate were secured in each experiment. Simultaneously with the reduction in glomerular filtration rate, there was a marked fall in the potassium excretion of the right relative to the left kidney. It is important to note that both the absolute and the relative rates of sodium excretion from the right kidney fell markedly during the periods of constriction, except for the last four periods in Table I in which

TABLE II

Effect of lowering glomerular filtration rate without $\mathrm{NaCl}$ diuresis

\begin{tabular}{|c|c|c|c|c|c|c|c|c|c|c|c|}
\hline \multirow{2}{*}{$\underset{(\min .)}{\text { Time }}$} & \multicolumn{2}{|c|}{$\begin{array}{c}\text { Urine } \\
\text { flow } \\
(m b . / m i n .)\end{array}$} & \multicolumn{2}{|c|}{$\begin{array}{c}\text { Inulin } \\
\text { clearance } \\
\text { (ml./min.) }\end{array}$} & \multicolumn{2}{|c|}{$\begin{array}{c}\text { Excreted } \\
\mathbf{K} \\
(\mu E q . / \min .)\end{array}$} & \multicolumn{2}{|c|}{$\begin{array}{c}\text { Excreted } \\
\mathrm{Na} \\
(\mu E q . / \min .)\end{array}$} & \multirow{2}{*}{$\begin{array}{l}\text { Glomerular } \\
\text { filtration } \\
\text { rate } \\
\mathbf{R} / \mathbf{L}\end{array}$} & \multirow{2}{*}{$\underset{\mathbf{R} / \mathbf{L}}{\text { Excreted }}$} & \multirow{2}{*}{$\begin{array}{c}\text { Excreted } \\
\mathbf{N a} \\
\mathbf{R} / \mathbf{L}\end{array}$} \\
\hline & $\mathbf{R}$ & $\mathbf{L}$ & $\mathbf{R}$ & $\mathbf{L}$ & $\mathbf{R}$ & $\mathbf{L}$ & $\mathbf{R}$ & $\mathbf{L}$ & & & \\
\hline & \multicolumn{11}{|c|}{ Prime: 400 mg. inulin } \\
\hline 0 & \multicolumn{11}{|c|}{ Sustaining infusion: Inulin, $10 \mathrm{mg} . / \mathrm{min} . ;$ mannitol, $2,400 \mu O \mathrm{sm} . / \mathrm{min}$. in water at $5 \mathrm{ml} . / \mathrm{min}$. } \\
\hline $\begin{array}{l}40-50 \\
51-56 \\
57-64\end{array}$ & $\begin{array}{l}1.92 \\
2.30 \\
2.30\end{array}$ & $\begin{array}{l}2.14 \\
2.44 \\
2.37\end{array}$ & $\begin{array}{l}36.4 \\
36.0 \\
35.0\end{array}$ & $\begin{array}{l}36.4 \\
35.4 \\
35.4\end{array}$ & $\begin{array}{l}61.3 \\
80.6 \\
93.6\end{array}$ & $\begin{array}{l}64.8 \\
83.2 \\
91.6\end{array}$ & $\begin{array}{l}118 \\
140 \\
134\end{array}$ & $\begin{array}{l}158 \\
167 \\
157\end{array}$ & $\begin{array}{l}1.0 \\
1.02 \\
0.99\end{array}$ & $\begin{array}{l}0.95 \\
0.97 \\
1.02\end{array}$ & $\begin{array}{l}0.75 \\
0.84 \\
0.85\end{array}$ \\
\hline 67 & \multicolumn{11}{|c|}{ Clamp inflated right renal artery } \\
\hline $\begin{array}{l}118-125 \\
128-133 \\
134-141 \\
145-151 \\
152-160\end{array}$ & $\begin{array}{l}1.97 \\
2.18 \\
1.94 \\
2.38 \\
2.45\end{array}$ & $\begin{array}{l}4.31 \\
4.84 \\
4.65 \\
4.48 \\
4.44\end{array}$ & $\begin{array}{l}26.1 \\
29.2 \\
24.0 \\
26.8 \\
29.2\end{array}$ & $\begin{array}{l}38.8 \\
39.6 \\
37.0 \\
35.6 \\
36.4\end{array}$ & $\begin{array}{l}53 \\
60 \\
47 \\
63 \\
69\end{array}$ & $\begin{array}{l}118 \\
127 \\
127 \\
130 \\
132\end{array}$ & $\begin{array}{l}76.3 \\
50.9 \\
36.6 \\
66.8 \\
60.9\end{array}$ & $\begin{array}{l}288 \\
335 \\
318 \\
308 \\
278\end{array}$ & $\begin{array}{l}0.67 \\
0.74 \\
0.65 \\
0.75 \\
0.80\end{array}$ & $\begin{array}{l}0.45 \\
0.47 \\
0.37 \\
0.49 \\
0.52\end{array}$ & $\begin{array}{l}0.27 \\
0.15 \\
0.12 \\
0.22 \\
0.22\end{array}$ \\
\hline
\end{tabular}



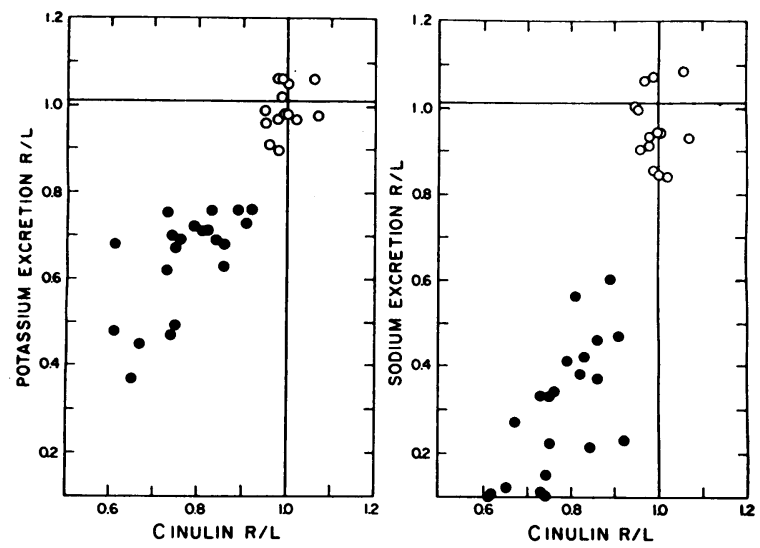

Fig. 1. Mass Plot of Data from Five Experiments in which a High Rate of Sodium Excretion Was Not Maintained

Open points represent control periods; solid points, periods in which the filtration rate in the right kidney was lowered.

the absolute rates of excretion of both sodium and potassium increased, although both remained low, relative to those on the control side. Figure 1 is a mass plot of the data from five experiments (not including those in Tables I and II) in four different dogs. In the left half of Figure 1, the ratio of the rates of potassium excretion, right to left kidney, is plotted against the ratio of the clearance of inulin. A decrease in the ratio of potassium excretion occurs at all levels of reduction of filtration rate. In the right half of Figure 1, the ratio of sodium excretion is similarly plotted. When filtration rate is lowered to any measurable degree, a marked fall in sodium excretion is evident.
In the interpretation of the results of these experiments, the absolute rate of sodium excretion has been considered to be indicative of the load of sodium to the distal tubule. In all of these experiments the fall in the sodium excretion of the right kidney, when compared to the left, exceeded the relative decrease in the clearance of inulin. The fall in the rate of potassium excretion of the right relative to the left kidney is interpreted as a consequence of the decrease in sodium available for exchange with potassium in the distal tubules, as manifested by the marked drop in sodium excretion. A fall in the ratio also could be effected by a decreased filtered load of potassium if the filtered potassium did contribute significantly to the excreted potassium. In addition, dropping out of nephron units during constriction of the renal artery could account for a fall in potassium excretion. However, the latter explanations are unlikely in light of the results of experiments performed during high rates of sodium excretion.

\section{Reduction of the glomerular filtration rate during high rates of sodium excretion}

These experiments were designed to assure adequate loads of sodium in the distal tubule despite reductions in the glomerular filtration rate. Table III gives the data from an experiment in which adequate sodium excretion was secured by the administration of a mercurial diuretic and the infusion of isotonic saline. During the control periods, the clearance of inulin and the excretion of potassium and sodium from each kidney were

TABLE III

Effect of reducing glomerular filtration rate during mercurial diuresis

\begin{tabular}{|c|c|c|c|c|c|c|c|c|c|c|c|c|c|c|c|c|}
\hline \multirow{2}{*}{$\underset{(\min .)}{\text { Time }}$} & \multicolumn{2}{|c|}{$\begin{array}{c}\text { Urine } \\
\text { flow } \\
\text { (ml. } / \min .)\end{array}$} & \multicolumn{2}{|c|}{$\begin{array}{c}\text { Inulin } \\
\text { clearance } \\
(m l . / m i n .)\end{array}$} & \multicolumn{2}{|c|}{$\begin{array}{c}\text { Excreted } \\
\mathrm{K} \\
(\mu E q . / \min .)\end{array}$} & \multicolumn{2}{|c|}{$\begin{array}{c}\text { Excreted } \\
\mathrm{Na} \\
(\mu \mathrm{E} . / \min .)\end{array}$} & \multicolumn{2}{|c|}{$\begin{array}{c}\text { Excreted } \\
\mathrm{Cl}^{-} \\
(\mu E q . / \min .)\end{array}$} & \multirow{2}{*}{$\underset{\mathbf{K}}{\underset{(m E q . / L .)}{\text { Plasma }}}$} & \multicolumn{2}{|c|}{$\begin{array}{c}\text { Filtered } \\
\mathrm{K} \\
(\mu E q . / \min .)\end{array}$} & \multirow{2}{*}{$\begin{array}{c}\text { Glomer- } \\
\text { ular fil- } \\
\text { tration } \\
\text { rate } \\
\mathbf{R} / L\end{array}$} & \multirow{2}{*}{$\begin{array}{c}\text { Ex- } \\
\text { creted } \\
\mathbf{K} \\
\mathbf{R} / \mathrm{L}\end{array}$} & \multirow{2}{*}{$\begin{array}{c}\text { Ex- } \\
\text { creted } \\
\text { Na } \\
\mathrm{R} / \mathrm{L}\end{array}$} \\
\hline & $\mathbf{R}$ & L & $\mathbf{R}$ & $\mathbf{L}$ & $\mathbf{R}$ & $\mathbf{L}$ & $\mathbf{R}$ & $\mathrm{L}$ & $\mathbf{R}$ & $\mathrm{L}$ & & $\mathbf{R}$ & L & & & \\
\hline & \multicolumn{16}{|c|}{ Prime: Inulin, $700 \mathrm{mg} . ;$ Salyrgan ${ }^{\circledR}, 2 \mathrm{ml}$. I.V. } \\
\hline & \multicolumn{16}{|c|}{$\begin{array}{l}\text { Sustaining infusion: Inulin, } 12.5 \mathrm{mg} . / \mathrm{min} . ; \mathrm{NaCl}, 1,800 \mu E q . / \min . ; \\
\text { in water at } 12 \mathrm{ml} . / \mathrm{min} .\end{array}$} \\
\hline $\begin{array}{l}65-71 \\
72-77 \\
81-85\end{array}$ & $\begin{array}{l}5.59 \\
7.80 \\
9.70\end{array}$ & $\begin{array}{l}5.50 \\
7.05 \\
8.90\end{array}$ & $\begin{array}{l}58.6 \\
63.0 \\
57.6\end{array}$ & $\begin{array}{l}58.4 \\
56.7 \\
56.0\end{array}$ & $\begin{array}{l}15.3 \\
16.6 \\
19.4\end{array}$ & $\begin{array}{l}17.5 \\
18.2 \\
21.6\end{array}$ & $\begin{array}{r}954 \\
1,200 \\
1,470\end{array}$ & $\begin{array}{r}929 \\
1,081 \\
1,370\end{array}$ & $\begin{array}{r}825 \\
1,060 \\
1,310\end{array}$ & $\begin{array}{r}813 \\
959 \\
1,190\end{array}$ & $\begin{array}{l}4.37 \\
4.37 \\
4.34\end{array}$ & $\begin{array}{l}256 \\
276 \\
250\end{array}$ & $\begin{array}{l}255 \\
248 \\
244\end{array}$ & $\begin{array}{l}1.00 \\
1.10 \\
1.03\end{array}$ & $\begin{array}{l}0.87 \\
0.91 \\
0.90\end{array}$ & $\begin{array}{l}1.03 \\
1.11 \\
1.07\end{array}$ \\
\hline 90 & \multicolumn{16}{|c|}{ Clamp inflated right renal artery } \\
\hline $\begin{array}{l}174-178 \\
180-185 \\
188-192 \\
193-198 \\
200-205\end{array}$ & $\begin{array}{l}5.37 \\
6.0 \\
8.26 \\
6.41 \\
6.60\end{array}$ & $\begin{array}{r}9.50 \\
10.10 \\
9.75 \\
8.10 \\
8.43\end{array}$ & $\begin{array}{l}40.0 \\
42.6 \\
52.0 \\
46.0 \\
46.0\end{array}$ & $\begin{array}{l}64.1 \\
62.5 \\
63.6 \\
60.2 \\
64.5\end{array}$ & $\begin{array}{l}52.3 \\
55.8 \\
62.6 \\
57.5 \\
54.1\end{array}$ & $\begin{array}{l}54.9 \\
59.1 \\
61.3 \\
59.0 \\
58.1\end{array}$ & $\begin{array}{r}816 \\
911 \\
1,270 \\
1,019 \\
1,028\end{array}$ & $\begin{array}{l}1,420 \\
1,520 \\
1,500 \\
1,340 \\
1,340\end{array}$ & $\begin{array}{r}726 \\
820 \\
1,130 \\
913 \\
925\end{array}$ & $\begin{array}{l}1,290 \\
1,380 \\
1,340 \\
1,160 \\
1,190\end{array}$ & $\begin{array}{l}4.20 \\
4.23 \\
4.36 \\
4.45 \\
4.48\end{array}$ & $\begin{array}{l}168 \\
180 \\
226 \\
205 \\
206\end{array}$ & $\begin{array}{l}269 \\
264 \\
278 \\
268 \\
289\end{array}$ & $\begin{array}{l}0.63 \\
0.68 \\
0.82 \\
0.76 \\
0.71\end{array}$ & $\begin{array}{l}0.95 \\
0.94 \\
1.03 \\
0.98 \\
0.93\end{array}$ & $\begin{array}{l}0.57 \\
0.60 \\
0.85 \\
0.76 \\
0.77\end{array}$ \\
\hline
\end{tabular}


close to equal. The glomerular filtration rate in the right kidney was then reduced by compression of the renal artery. The elapsed time between the control periods and the first experimental period represents the time necessary to achieve a stable reduction of the glomerular filtration rate. During this time, the full effect of the mercurial and sodium chloride infusion on potassium excretion also becomes manifest, as is shown by the increase in the absolute rate of potassium excretion. The filtration rate was reduced by 19 to 37 per cent in the right kidney. Despite a reduced filtered load of potassium, the potassium excretion of the right kidney was not decreased relative to that of the left kidney. The fall in the rate of sodium excretion from the experimental kidney was approximately proportional to the reduction in the glomerular filtration rate. However, despite the lowered filtration rate, the absolute rate of sodium excretion remained high. The data from a similar experiment in a different dog are plotted in Figure 2. Again, a mercurial diuretic and an infusion of isotonic sodium chloride assured adequate sodium excretion. The solid bars represent the data from the experimental kidney, and the stippled bars, the data from the control kidney. The total length of each bar represents the filtered load of potassium in each kidney, and the distance of the bars below the zero line, the rates of excretion of potassium. In the three control periods

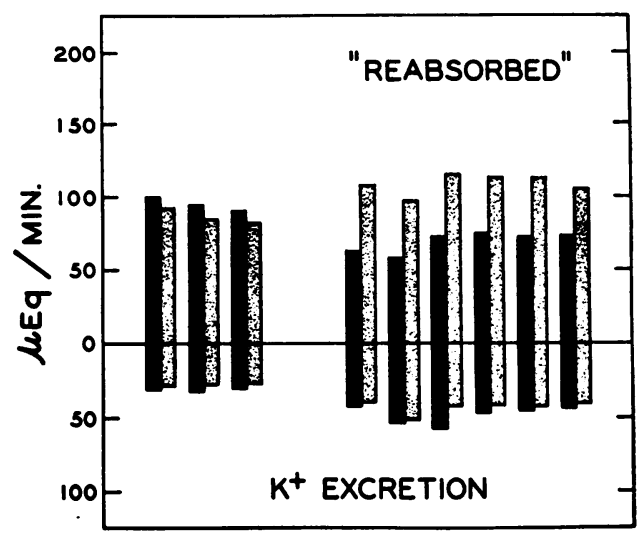

Fig. 2. Potassium Excretion During Infusion of a Mercurial Diuretic and NaCl

Each pair of bars (solid, control kidney; stippled, experimental kidney) represents a clearance period. The first three pairs are control periods. The total length of each bar represents the filtered load of potassium; the distance of each bar below the zero line, the rate of excretion of potassium.

shown on the left in the figure, the rate of potassium excretion by the experimental kidney is slightly greater than that of the control kidney. During the periods of compression of the renal artery shown on the right in the figure, despite the marked decrease in the filtered load of potassium of the experimental kidney relative to the control kidney, the rate of excretion by the experimental kidney remained slightly higher than that of the

TABLE IV

Effect of reducing glomerular filtration rate during $\mathrm{NaHCO}_{5}$-Diamox ${ }^{\circledR}$ diuresis

\begin{tabular}{|c|c|c|c|c|c|c|c|c|c|c|c|c|c|c|c|c|}
\hline \multirow{2}{*}{$\underset{(\min .)}{\operatorname{Time}}$} & \multicolumn{2}{|c|}{$\begin{array}{l}\text { Urine } \\
\text { flow } \\
\text { (ml./min.) }\end{array}$} & \multicolumn{2}{|c|}{$\begin{array}{l}\text { Inulin } \\
\text { clearance } \\
\text { (ml./min.) }\end{array}$} & \multicolumn{2}{|c|}{$\begin{array}{l}\text { PAH } \\
\text { clearance } \\
(m l . / \text { min. })\end{array}$} & \multicolumn{2}{|c|}{$\underset{(\mu E q . / \min .)}{\text { Excreted }}$} & \multicolumn{2}{|c|}{$\begin{array}{l}\text { Excreted } \\
\mathrm{Na} \\
(\mu E q . / \min .)\end{array}$} & \multirow{2}{*}{$\underset{(m E q . / L .)}{\stackrel{\text { Plasma }}{K}}$} & \multicolumn{2}{|c|}{$\begin{array}{l}\text { Filtered } \\
\mathrm{K} \\
(\mu E q . / \min .)\end{array}$} & \multirow{2}{*}{$\begin{array}{c}\text { Glomer- } \\
\text { ular fil- } \\
\text { tration } \\
\text { rate } \\
\text { R/L }\end{array}$} & \multirow{2}{*}{$\begin{array}{c}\text { Ex- } \\
\text { creted } \\
\mathbf{K} \\
\mathbf{R} / \mathrm{L}\end{array}$} & \multirow{2}{*}{$\begin{array}{c}\text { Ex- } \\
\text { creted } \\
\mathrm{Na} \\
\mathrm{R} / \mathrm{L}\end{array}$} \\
\hline & $\mathbf{R}$ & L & $\mathbf{R}$ & L & $\mathbf{R}$ & $\mathbf{L}$ & $\mathbf{R}$ & L & $\mathbf{R}$ & L & & $\mathbf{R}$ & L & & & \\
\hline & \multicolumn{16}{|c|}{ Prime: Inulin, $500 \mathrm{mg} . ;$ Diamox $\AA, 250 \mathrm{mg}$. } \\
\hline 0 & \multicolumn{16}{|c|}{$\begin{aligned} \text { Sustaining infusion: Inulin, } 10 \mathrm{mg} . / \mathrm{min} . ; \mathrm{PAH}, 6 \mathrm{mg} . / \mathrm{min} . ; \mathrm{NaHCO}_{3}, 1,800 \mu E q . / \mathrm{min} . ; \\
\text { Diamox }{ }^{\circledR}, 1.5 \mathrm{mg} . / \mathrm{min} . ; \text { in water at } 12 \mathrm{ml} . / \mathrm{min} .\end{aligned}$} \\
\hline $\begin{array}{l}39-45 \\
47-52 \\
53-57 \\
58-62\end{array}$ & $\begin{array}{l}5.90 \\
6.34 \\
7.86 \\
8.28\end{array}$ & $\begin{array}{l}6.25 \\
6.89 \\
8.25 \\
8.75\end{array}$ & $\begin{array}{l}46.0 \\
45.0 \\
42.5 \\
43.0\end{array}$ & $\begin{array}{l}47.5 \\
49.0 \\
45.0 \\
46.0\end{array}$ & $\begin{array}{l}179 \\
216 \\
199 \\
208\end{array}$ & $\begin{array}{l}190 \\
197 \\
212 \\
210\end{array}$ & $\begin{array}{l}121 \\
120 \\
136 \\
146\end{array}$ & $\begin{array}{l}137 \\
139 \\
147 \\
162\end{array}$ & $\begin{array}{l}1,008 \\
1,016 \\
1,180 \\
1,216\end{array}$ & $\begin{array}{l}1,232 \\
1,216 \\
1,428 \\
1,476\end{array}$ & $\begin{array}{l}4.46 \\
4.34 \\
3.97 \\
3.50\end{array}$ & $\begin{array}{l}205 \\
195 \\
169 \\
151\end{array}$ & $\begin{array}{l}212 \\
213 \\
179 \\
161\end{array}$ & $\begin{array}{l}0.97 \\
0.92 \\
0.94 \\
0.93\end{array}$ & $\begin{array}{l}0.88 \\
0.87 \\
0.93 \\
0.90\end{array}$ & $\begin{array}{l}0.82 \\
0.84 \\
0.83 \\
0.82\end{array}$ \\
\hline 65 & \multicolumn{16}{|c|}{ Clamp inflated right renal artery } \\
\hline $\begin{array}{l}105-108 \\
110-113 \\
115-118 \\
120-124 \\
125-130 \\
132-136 \\
139-143\end{array}$ & $\begin{array}{l}4.76 \\
5.06 \\
5.14 \\
4.50 \\
5.50 \\
5.29 \\
5.36\end{array}$ & $\begin{array}{l}9.31 \\
8.14 \\
8.56 \\
7.45 \\
8.37 \\
8.19 \\
7.95\end{array}$ & $\begin{array}{l}29.0 \\
31.0 \\
30.8 \\
28.1 \\
33.6 \\
34.1 \\
30.6\end{array}$ & $\begin{array}{l}38.1 \\
41.0 \\
44.0 \\
41.0 \\
46.6 \\
41.6 \\
42.5\end{array}$ & $\begin{array}{l}182 \\
180 \\
179 \\
155 \\
152 \\
143 \\
145\end{array}$ & $\begin{array}{l}215 \\
208 \\
222 \\
195 \\
184 \\
172 \\
172\end{array}$ & $\begin{array}{l}214 \\
229 \\
226 \\
209 \\
215 \\
201 \\
199\end{array}$ & $\begin{array}{l}246 \\
242 \\
261 \\
224 \\
243 \\
236 \\
222\end{array}$ & $\begin{array}{l}652 \\
632 \\
652 \\
596 \\
744 \\
712 \\
732\end{array}$ & $\begin{array}{l}1,252 \\
1,196 \\
1,264 \\
1,148 \\
1,264 \\
1,176 \\
1,148\end{array}$ & $\begin{array}{l}3.67 \\
3.68 \\
3.69 \\
3.70 \\
3.76 \\
3.78 \\
3.79\end{array}$ & $\begin{array}{l}106 \\
114 \\
114 \\
104 \\
126 \\
129 \\
116\end{array}$ & $\begin{array}{l}140 \\
151 \\
162 \\
152 \\
175 \\
157 \\
162\end{array}$ & $\begin{array}{l}0.76 \\
0.76 \\
0.70 \\
0.68 \\
0.72 \\
0.82 \\
0.72\end{array}$ & $\begin{array}{l}0.87 \\
0.95 \\
0.87 \\
0.93 \\
0.88 \\
0.85 \\
0.90\end{array}$ & $\begin{array}{l}0.52 \\
0.53 \\
0.51 \\
0.52 \\
0.59 \\
0.61 \\
0.64\end{array}$ \\
\hline
\end{tabular}




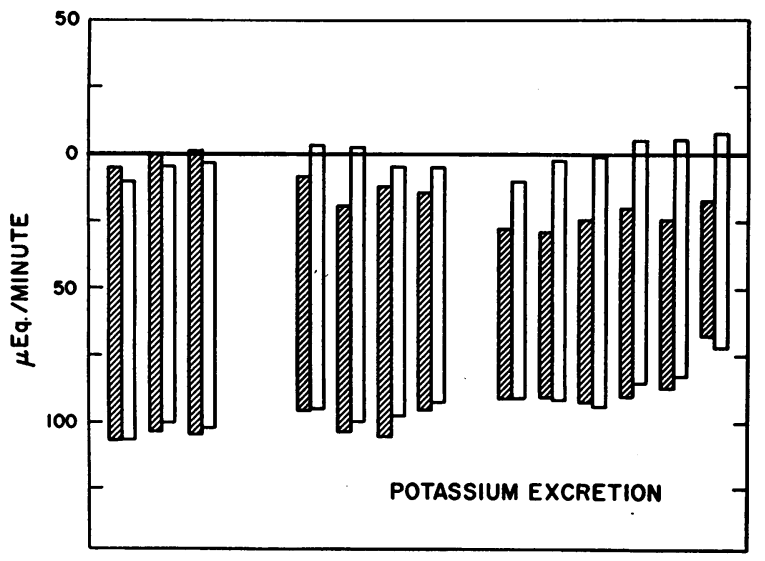

Fig. 3. Potassium Excretion During Infusion of Diamox AND $\mathrm{NaHCO}_{3}$

Each pair of bars (cross-hatched, control kidney; open, experimental kidney) represents a clearance period. The first three pairs are control periods; the other two groups of bars are data obtained during two different settings of the arterial clamp. The total length of each bar represents the filtered load of potassium; the distance of the top of the bar from the zero line, net secretion of potassium; the distance of the bottom of the bar from the zero line, the rate of potassium excretion.

control kidney. The greater rate of potassium excretion from the experimental kidney during the third period of compression probably represents a dead space error due to a rising urine flow. The length of the bars above the zero line during the periods of compression of the artery shows the variation in reabsorption of potassium which would be needed to maintain an equal rate of potassium excretion, if the filtered potassium did contribute significantly to the excreted potassium. This would require a decrease in the proportion of the filtered load of potassium which is reabsorbed, when the filtered load is decreased by clamping the renal artery.

In the experiments in which mercurial diuretics were used to produce a high rate of sodium excretion, the excreted potassium was only a small portion of the amount filtered. The same independence of excretion rate from filtered load was found when potassium excretion was equal to or greater than the amount filtered. A high rate of excretion of sodium and potassium was made possible by the administration of Diamox ${ }^{\circledR}$, a carbonic-anhydrase inhibitor. A sustaining infusion of sodium bicarbonate was given to prevent depletion of bicarbonate stores. The data from an experiment in which the rate of potassium excretion exceeded the filtered load are given in Table IV. Control periods were secured to establish the rates of potassium excretion by the two kidneys. The glomerular filtration rate was then reduced by 12 to 27 per cent with essentially no change in the relative rates of potassium excretion by the two kidneys. As in the two previous experiments, the absolute rate of sodium excretion remained high. The data from a similar experiment are plotted in Figure 3. The design of this figure is similar to that of Figure 2. The cross-hatched bars represent data from the experimental kidney, and the open bars, data from the control kidney. The length of the bars represents the rate of filtration of potassium; the distance of the bottom of the bars from the zero line, the rate of potassium excretion; the distance of the top of the bars below the zero line, the net secretion of potassium. The rate of excretion of potassium was high and in some periods exceeded the filtered load. Following the control periods the filtered load of potassium in the experimental kidney relative to the control kidney was decreased by lowering the filtration rate. This is shown by the shorter length of the shaded bars. In this experiment, as in the previous experiments, the rates of potassium excretion by the two kidneys remained essentially equal despite marked differences in the filtered loads.

A similar independence of excreted potassium from the filtered load of potassium was found in experiments in which sodium sulfate was used to promote a high rate of sodium excretion. Figure 4 summarizes the experimental data from multiple experiments in five dogs. The three materials used to produce an adequately high rate of sodium excretion were a mercurial diuretic (Salyrgan ${ }^{\circledR}$ ), sodium sulfate, and Diamox ${ }^{\circledR}$. The top half of the figure represents the data from three experiments in one dog; the bottom half of the figure, the data from experiments in four different dogs. Each point represents one clearance period. In the left half of the figure the ratio of the rates of potassium excretion, right to left kidney, is plotted against the ratio of the clearances of inulin. The right half of the figure is a similar plot of the sodium excretion. The ratio of the rates of potassium excretion from the two kidneys remained essentially unchanged with reductions 

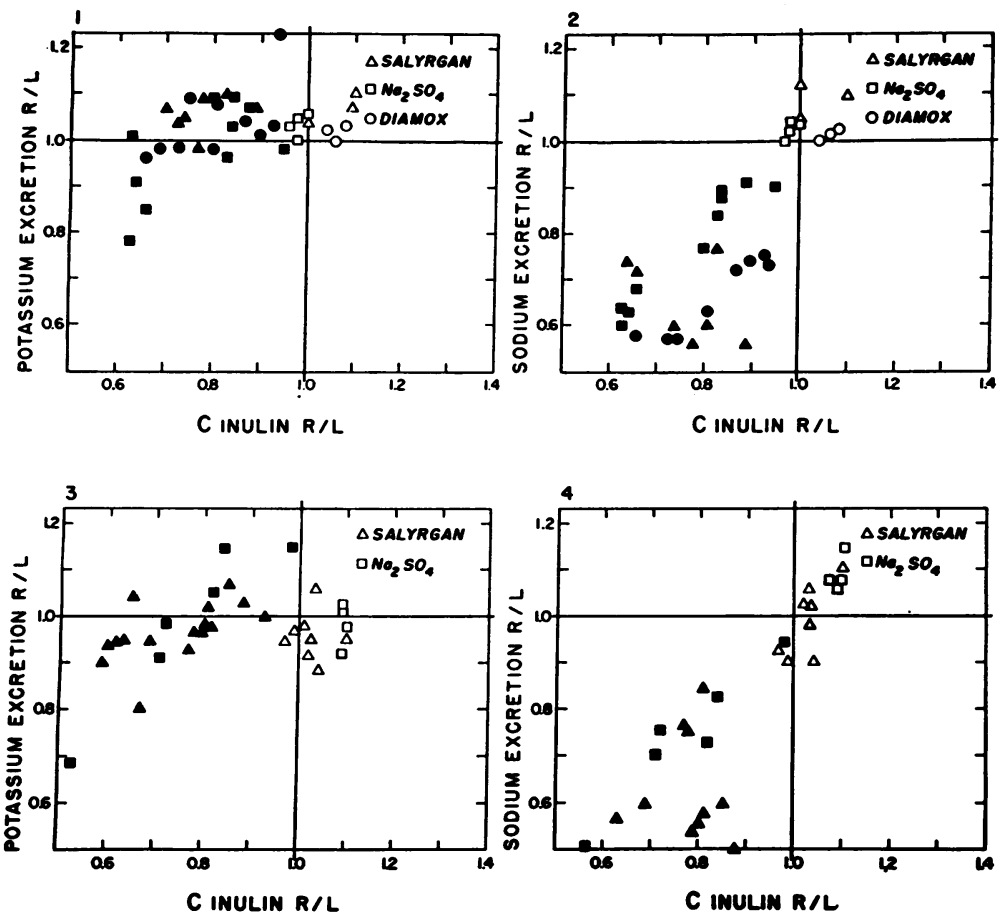

Fig. 4. Mass Plot of Data from Experiments in which Sodium ExCREtion was Maintained at High Rates

The upper half of the figure represents three experiments in one dog; the lower half, one experiment in each of four different dogs. The open points represent control clearance periods; the solid points, periods in which the filtration rate in the right kidney was lowered. (Two points in Chart 2 and six points in Chart 4 , in which the ratio of sodium excretion, $R / L$, was less than 0.5 , are not plotted.)

of the clearance of inulin of the experimental kidney to 60 to 65 per cent of that of the control kidney. The fall in the sodium excretion of the "clamped" kidney was proportional to or slightly greater than the reduction of the clearance of inulin. The results were independent of the agent used to produce a sodium diuresis. ${ }^{2}$

2 In one dog only two levels of reduction of the glomerular filtration rate could be secured by inflation of the cuff; i.e., 5 to 10 per cent and 50 to 53 per cent. At the 5 to 10 per cent level of reduction, potassium excretion was maintained. However, despite a marked sodium diuresis, when the filtration rate was reduced to 50 to 53 per cent, potassium excretion fell by approximately 50 per cent. The concentrations of $\mathrm{Na}, \mathrm{K}$, and inulin remained equal to that of the control kidney. It was suspected that the clamp, by error, had been placed so as to encircle two branches of the renal artery, and that with compression of the clamp, one branch was completely

\section{DISCUSSION}

In these experiments the glomerular filtration rate of one kidney has been reduced by mechani-

shut off and the other branch unaffected. To determine whether the entire kidney was being perfused when the clamp was set so as to reduce the glomerular filtration rate 50 per cent, fluorescein was injected rapidly intravenously. Following the appearance of the dye in the urine, the cuff was inflated with pressure sufficient to completely occlude the renal artery. The animal was sacrificed and the kidney immediately removed. A coronal section of the kidney was made and the distribution of the dye was determined by placing the kidney in ultraviolet light. Approximately one-half of the cut section was fluorescent and the other half was not; the dye was distributed only in one sagittal half of the kidney. In this particular preparation the mechanism of reduction of the glomerular filtration rate would seem to have been a dropping out of nephron units due to the complete occlusion of one branch of the renal artery. 
cal compression of the renal artery. There are two mechanisms which could account for the observed decrease in glomerular filtration rate. The first, and the more tenable in view of the experimental results, is a general reduction of the glomerular filtration rate involving all the nephrons. The second possible mechanism is complete interruption of blood flow to some of the glomeruli with consequent dropping out of functioning nephron units. The glomerular filtration rate has been reduced up to 40 per cent in one kidney with no decrease in the rate of potassium excretion as compared to the control kidney. If a dropping out of functioning nephron units were the mechanism for the reduction of the glomerular filtration rate, the experimental results could be explained only if it were further postulated that these particular nephrons did not take part in the normal excretion of potassium. However, these postulates would not explain the dependence of potassium excretion on a high rate of sodium excretion during reduction of the glomerular filtration rate. Evidence against dropping out of nephron units was also found by Thompson, Barrett, and Pitts (6) who reduced the glomerular filtration rate in dogs by inflating a balloon in the abdominal aorta and found no change in the maximum tubular reabsorption of glucose even when the glomerular filtration rate was significantly reduced. In some of the present experiments, during sodium diuresis when the reduction in filtration rate exceeded 40 per cent, there was a decreased rate of potassium excretion as compared to the control kidney. At these levels of reduction of filtration rate a decrease in the rate of potassium excretion may be due either to a loss of functioning nephron units or to an inadequate load of sodium to the exchange mechanism in some of the nephrons.

The independence of potassium excretion from the filtered load of potassium during sodium diuresis cannot reasonably be explained by any changes in potassium reabsorption. If the filtered potassium did contribute to the excreted potassium, the proximal tubules would have to reabsorb a smaller per cent of the filtered load during the periods of compression of the artery. A reabsorptive mechanism of this sort, which decreased the per cent of the load reabsorbed when the load presented to it is decreased, would show behavior exactly opposite to all other reabsorptive mechanisms which have been studied. Moreover, this would necessitate the assumption that the reabsorptive mechanism could modify its activity so as to leave unreabsorbed the same absolute amount of potassium even though the concentration of the potassium remaining in the lumen varied even more than the changing filtered load. This would require some means for the tubule to sense the volume flow in the lumen, integrate this with the concentration, and reabsorb potassium accordingly. In the experiments in which the rate of potassium excretion was high, in some periods there was net secretion by the experimental kidney and net reabsorption by the control kidney. Similarly in these experiments, variation in the proximal reabsorption of potassium is an unlikely mechanism for maintaining equality of potassium excretion. It has been suggested previously that the major source of urinary potassium is potassium secreted by the renal tubules (7). The ability of the tubules to reabsorb the entire filtered load of potassium has been shown in many studies in which potassium virtually disappeared from the urine of human subjects or animals depleted of potassium. The results of the present experiments are in complete accord with the hypothesis that reabsorption of filtered potassium is essentially complete and that the source of urinary potassium is secreted potassium. This seems to be the case during both low and high rates of potassium excretion.

In this study independence of potassium excretion from filtered potassium could be demonstrated only during sodium diuresis. No differences pertinent to the interpretation of these experiments were found among the various diuretics used. In the experiments in which no diuretic agent was administered and the absolute rate of sodium excretion fell to low levels, there was a marked fall in the relative rate of potassium excretion when the glomerular filtration rate was reduced. The fall in the rate of potassium excretion is interpreted as due to a decrease in the amount of sodium available for exchange with potassium. The dependence of potassium excretion on sodium lends strong support to the thesis that potassium is secreted in the distal tubule by the exchange of potassium for sodium (1). 
SUM MARY

The excretion of potassium was studied in the dog during reduction of the glomerular filtration rate by means of an inflatable cuff placed around one renal artery. In experiments in which no attempt was made to maintain high rates of sodium excretion, potassium excretion fell with the decrease in the glomerular filtration rate. When high rates of sodium excretion were maintained by administration of mercurials, sodium sulfate, or Diamox ${ }^{\circledR}$, the rate of potassium excretion was maintained in spite of reductions of the glomerular filtration rate by up to 40 per cent. This was true both at low and high rates of potassium excretion. The results support the interpretation that reabsorption of filtered potassium is essentially complete, and that the urinary potassium is derived from secreted potassium. The dependence of potassium excretion on sodium excretion provides evidence that the secretion of potassium occurs by an exchange of potassium for sodium in the distal tubule.

\section{REFERENCES}

1. Berliner, R. W., Kennedy, T. J., Jr., and Hilton, J. G. Renal mechanisms for excretion of potassium. Amer. J. Physiol. 1950, 162, 348.

2. Berliner, R. W., and Davidson, D. G. Production of hypertonic urine in the absence of pituitary antidiuretic hormone. J. clin. Invest. 1957, 36, 1416.

3. Walser, M., Davidson, D. G., and Orloff, J. The renal clearance of alkali-stable inulin. J. clin. Invest. $1955,34,1520$.

4. Bratton, A. C., and Marshall, E. K., Jr. A new coupling component for sulfanilamide determination. J. biol. Chem. 1939, 128, 537.

5. Sanderson, P. H. Potentiometric determination of chloride in biological fluids. Biochem. J. 1952, 52, 502.

6. Thompson, D. D., Barrett, M. J., and Pitts, R. F. Significance of glomerular perfusion in relation to variability of filtration rate. Amer. J. Physiol. 1951, 167, 546.

7. Berliner, R. W., Kennedy, T. J., Jr., and Orloff, J. Factors affecting the transport of potassium and hydrogen ions by the renal tubules. Arch. int. Pharmacodyn. 1954, 97, 299. 